Walisongo Law Review (Walrev), Vol 2 No. 1 (2020)

DOI: 10.21580/Walrev/2020.2.1.5555

Copyright $@ 2020$ Walisongo Law Review (Walrev)

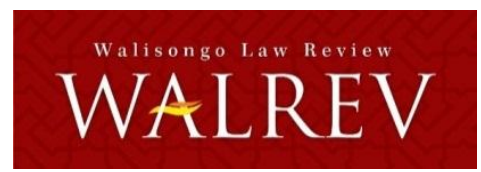

\title{
Legal Protection for Disability Workers in Semarang: Case Study at PT. Samwon Busana Indonesia
}

\author{
Retno Indarti ${ }^{1}$, Novita Dewi Masyithoh ${ }^{2}$, Tri Nurhayati ${ }^{3}$ \\ Afiliasi: Universitas Islam Negeri (UIN) Walisongo, Semarang \\ Email: retno@gmail.com¹; novitadewi@yahoo.co.id ${ }^{2}$; \\ trinurhayati@walisongo.ac.id ${ }^{3}$
}

\begin{abstract}
The purpose of this study is to measure legal protection and employment opportunities for persons with disabilities who work in various companies in the city of Semarang, Central Java. As is known, the right to work for citizens is regulated in Article 27 Paragraph 2 of the 1945 Constitution, which mandates the right of citizens to get a decent job and life. Every citizen has the same rights and the state (government) has regulated these rights in terms of obtaining employment without exception, including persons with disabilities. This study uses a juridical-empirical (non-doctrinal) approach, which examines how employment opportunities and legal protection of persons with disabilities in the city of Semarang, especially in PT. Samwon Clothing Indonesia. Primary data sources were obtained from PT. Samwon Busana Indonesia through interviews, secondary data in the form of legal material. Data Collection Method with Interview and Documentation methods, Data Analysis is done by a descriptive method. The results showed that
\end{abstract}


employment opportunities for workers with disabilities in the city of Semarang, especially in PT Samwon Busana Indonesia had fulfilled one percent of the total employees. The total disability workers at the company are 14 out of a total of 1317 employees. In terms of legal protection, all employees both with disabilities and do not get the same rights and opportunities to be treated fairly. In addition, fulfillment of the rights of workers with disabilities is also fulfilled without discrimination.

Tujuan penelitian ini adalah untuk mengukur perlindungan hukum dan adanya kesempatan kerja bagi penyandang disabilitas yang bekerja di berbagai perusahaan di Kota Semarang, Jawa Tengah. Sebagaimana diketahui, hak bekerja bagi warga negara diatur dalam Pasal 27 Ayat (2) Undang-Undang Dasar Negara Republik Indonesia Tahun 1945, yang isinya memandatkan hak warga negara untuk memperoleh pekerjaan dan kehidupan yang layak. Setiap warga negara memiliki hak yang sama dan negara (pemerintah) telah mengatur mengenai hak-hak tersebut dalam hal memperoleh pekerjaan tanpa terkecuali, termasuk penyandang disabilitas. Penelitian ini menggunakan pendekatan yuridis-empiris (non-doktrinal), meneliti tentang bagaimana kesempatan kerja dan perlindungan hukum penyandang disabilitas di Kota Semarang, khususnya di PT. Samwon Busana Indonesia. Sumber data primer diperoleh dari PT. Samwon Busana Indonesia melalui wawancara, data sekunder berupa bahan hukum. Metode Pengumpulan Data dengan metode wawancara dan dokumentasi. Analisis Data dilakukan dengan metode deskriptif. Hasil Penelitian menunjukkan bahwa kesempatan kerja bagi pekerja disabilitas di Kota Semarang, khususnya di PT Samwon Busana Indonesia telah memenuhi satu persen dari total karyawan. Total pekerja disabilitas di perusahaan tersebut sebanyak 14 karyawan dari total 1317 karyawan. Dari sisi perlindungan hukum, semua karyawan baik disabilitas maupun tidak mendapatkan hak dan kesempatan yang sama untuk diperlakukan secara adil. Selain itu, pemenuhan terhadap hak-hak pekerja disabilitas juga terpenuhi tanpa adanya sebuah diskriminasi. 
Retno Indarti dkk, Legal Protection for Disability Workers...

Keywords: Job opportunities; Labor; Persons with disabilities; PT Samwon Busana Indonesia

\section{Introduction}

Workers based on Article 1 Paragraph (2) of Law Number 13 of 2003 concerning Manpower are all people who are able to do work to produce goods and/or services both to meet their own needs and for the community. From this explanation, it can be concluded that everyone who is able to work is called a workforce. The population that can be said as labor is the population that has entered the working age. According to the Central Statistics Agency, residents who have entered working age are residents aged 15 years and over (Badan Pusat Statistik 2019). Based on the 2015-2045 population projections from the 2015 Intercensal Population Survey (Supas), Indonesia's population will reach 269.6 million in 2020. Whereas many as 66.07 million people fall into the category of unproductive age (o-4 years), and 185.34 million people are productive age group (15-64 years), and 18.2 million people are unproductive population (65+ years) (databooks: 2019).

In general, residents who have entered the working age have the same opportunity in terms of getting a job. The right to work for all citizens is regulated in the 1945 Constitution of the Republic of Indonesia. As in Article 27 Paragraph (2), the 1945 Constitution states that "Every citizen has the right to work and a decent living for humanity". From this paragraph, it shows that every citizen has the right to get a job without the need to look for it with a decent income because this work must be provided and/or prepared by the state. In addition, the rights for citizens are also regulated in Article 28D Paragraph (2) of the 1945 Constitution which reads, "Everyone has the right to work and to receive fair and appropriate compensation and treatment in an employment relationship". From the above explanation, it can be concluded that every citizen has the same rights and the state has regulated the rights in terms of obtaining 
employment without exception. Likewise, people with disabilities must have their rights fulfilled.

Persons with disabilities based on Article 1 Paragraph (1) of Law Number 8 of 2016 concerning Persons with Disabilities is a person who has physical, mental and/or sensory limitations in a long period of time who is interacting with the environment can experience obstacles and difficulties to participate fully and effectively with other citizens. Often we see that many people with disabilities face difficulties because of their limitations in carrying out all activities. Being looked down on because they lack the ability and skills, is a barrier for people with disabilities and is no exception to discrimination. Fulfillment of the right to health insurance, schools, education services, and employment for persons with disabilities must be provided fairly, not only given to citizens who have physical and mental perfection, but also guarantees of rights for persons with disabilities.

According to the survey results, the Central Statistics Agency, National Labor Force Survey (sakernas) 2011, the total population of Indonesia is $237,641,326$ people with a working age of $171,755,077$. Whereas persons with disabilities themselves, when viewed from data from the Ministry of Defense Data and Information Center (Pusdatin) from the Ministry of Social Affairs, noted that in 2010 the number of persons with disabilities was 11,580,117 with of them 3,474,035 were persons with visual disabilities, 3,010,830 were physically disabled, 2,547,626 are people with hearing disabilities, 1,389. 614 are people with mental disabilities, and 1,158,012 are people with chronic disabilities. Furthermore, according to data from the Ministry of Manpower and Transmigration, in 2010 the number of people with disabilities was 7,126,409 people (International Labor Organization (ILO): 2013: 2).

Whereas in 2017 the Central Statistics Agency (BPS) released the National Labor Force Survey (Sakernas) data, where the population of people with disabilities has almost tripled compared to 2010, reaching 32.60 million people. Although the growth of the population with disabilities has increased, the number of dependencies or non- 
workforce age is still quite high, amounting to 48.82 percent of the total population (Wicaksono: 2018). In Indonesia, the existence of persons with disabilities which is still considered low by the community and excluded is one of the obstacles for persons with disabilities, especially in the world of work and employment opportunities for persons with disabilities. This is evidence that the lack of attention from the government and employers. Many obstacles that occur at this time become a factor that has the potential to affect the level of welfare for persons with disabilities.

Article 5 of Law Number 13 of 2003 concerning Manpower states that: "Every worker has the same opportunity without discrimination to obtain work". In his explanation, each worker has the same rights and opportunities to obtain decent work and livelihood without differentiating gender, ethnicity, race, religion, and political flow according to the interests and abilities of the relevant workforce, including equal treatment of persons defective.

In principle, all citizens both with a healthy physical condition and with disabilities have the same right to a position in law, especially regarding employment opportunities for persons with disabilities. This is confirmed in Article 27 Paragraph (1) of the 1945 Constitution: "All citizens are at the same position in law and government and must uphold the law and government with no exception".

The guarantee of employment opportunities must also be balanced with legal protection for persons with disabilities in accordance with Article 67 Paragraph (1) of Law Number 13 of 2003 concerning Manpower, which states that: "Employers who employ workers with disabilities must provide protection in accordance with the type and the degree of disability ". In an effort to protect, respect, and fulfill the rights of persons with disabilities, such as providing accessibility, personal protective equipment, health insurance, and others. However, many institutions, both government and private, have not implemented it enough to create weaknesses. The more discrimination that occurs with persons with disabilities especially related to work issues, the government should expressly provide legal protection for persons with disabilities and provide opportunities for 
people with disabilities to work like normal people in general and do not look physically so that it can become a barrier to them in working.

But it is different with PT. Samwon Busana Indonesia, a multinational company engaged in the export of garments, in running its business is always oriented to aspects of quality, employment, safety, safety, and occupational health $\left(\mathrm{K}_{3}\right)$ and environmental protection (Busana 2015). In addition to the quality aspect, PT. Samwon Busana Indonesia also provides equal employment opportunities and employs workers with normal physical and disability persons.

Based on the background of the problems that have been raised, the writer has formulated several main issues that will be discussed in this thesis. Here are some of the issues raised in this study: 1) How do the fulfillment of employment opportunities for persons with disabilities at PT Samwon Busana Indonesia Semarang?; 2) What is the legal protection of the employment rights of persons with disabilities at PT Samwon Busana Indonesia Semarang?

This research is qualitative legal research using a juridicalempirical approach (non-doctrinal), which is this type of research to find out how the law is implemented including the process of law enforcement (Amirudin and Zaenal Asikin 2004:134), which examines how employment opportunities and legal protection of persons with disabilities in PT. Samwon Clothing Indonesia. Primary data source obtained from PT. Samwon Busana Indonesia through interviews, Secondary Data in the form of legal material. Data Collection Method with Interview and Documentation methods. While the Data Analysis is done after the data is collected and then processed and analyzed together with the presentation process by descriptive method (Amirudin and Zaenal Asikin 2004:25).

\section{Job Opportunities and Legal Protection}

The term employment opportunities according to Tambunan, is including employment that has been occupied (employment) and is still vacant. From the vacant employment opportunities, there is a need for employment opportunities for unemployed people. The 
amount of employment that is still vacant or the labor requirements that are actually needed by a company depends on many factors, among which the most important is the business prospects or the output growth of the company, labor costs or salaries to be paid, and the price of the factors other factors of production that can replace the function of labor, for example, capital goods. Expanding productive employment opportunities does not mean only creating new business opportunities. But also efforts to increase work productivity which is generally accompanied by the provision of wages commensurate with what has been done by each worker (Tambunan 2002:80).

In addition, employment opportunities are the availability of employment opportunities to accommodate the workforce. Job opportunities are important indicators of an economy. Extensive employment opportunities reduce the number of unemployed people, increase the productivity of the population, and increase national production and income. Job opportunities or labor demand is derived from demand (derived demand) from the demand for goods and service products (Situmorang 2005). So it can be concluded that the employment opportunity here is a condition of the availability of job vacancies that can be utilized by residents who are looking for work.

Legal protection comes from two syllables namely protection and law. Based on the Big Indonesian Dictionary, protection is defined as a place of protection, things (deeds, and so on), processes, ways, actions to protect (KBBI: 2019). While the law is nothing but the protection of human interests in the form of norms or rules. Law as a collection of rules or rules contains content that is general and normative, general because it applies to everyone, and normative because it determines what is and is not permissible, and determines how to implement compliance with the rules (Mertokusumo 2007:39).

Based on the above understanding, there are several views regarding legal protection according to experts, as follows:

a. According to Satjipto Raharjo, legal protection is to provide protection for human rights that have been harmed by others 
and that protection is given to the community so that they can enjoy all the rights granted by law. The law can function to realize protection that is not only adaptive and flexible but also predictive and anticipatory. Law is needed for those who are weak and not yet strong socially, economically, and politically to obtain social justice (Raharjo 2000:53).

b. According to Phillipus M. Hadjon, legal protection is the protection of dignity and dignity, and recognition of human rights owned by legal subjects based on the legal provisions of arbitrariness (Hadjon 1987:1-2).

Based on the description above, it can be seen that legal protection is a form of protection given to everyone to maintain their dignity and status as human beings both in social, economic, and political terms by providing cover to avoid arbitrary acts carried out by the authorities The country is no exception to persons with disabilities.

The word disability comes from English, which is a different ability, which means that humans have different abilities. The term is used as a substitute for the term with a disability that has a negative sense of value and seems discriminatory (Rahayu, Sugi 2013:110). Pursuant to Article 1 Paragraph (1) of Law Number 8 of 2016 concerning Persons with Disabilities, provides an explanation of persons with disabilities that is, anyone who experiences physical, intellectual, mental, and/or sensory limitations in a long period of time interacting with the environment can experience obstacles and difficulties to participate fully and effectively with other citizens based on equal rights.

According to Law Number 4 of 1997 concerning Persons with Disabilities, there are three types of persons with disabilities, including Physical Disabilities (Reefani 2013:17), among others: Body Disabilities (physically disabled); Vision Sense Disorders (blind people); Hearing Loss (Deaf); Speech Disorders (Tuna speech); Mental disability; and Double tuna (double disability).

According to Article 41 paragraph (2) of Law Number 39 of 1999 concerning Human Rights regulates that every person with 
disabilities/disabilities, elderly people, pregnant women, and children, are entitled to special facilities and treatment. Meanwhile according to Article 5 of Law Number 8 of 2016 concerning Persons with Disabilities states that persons with disabilities have the right to live, free from stigma, privacy, justice, and legal protection, the right to get an education, get a job, entrepreneurship and cooperatives, obtain health, the right to politics, religious rights, sports rights, cultural and tourism rights, the right to social welfare, the right to get accessibility, public services, the right to protect from disasters, the right to get habilitation and rehabilitation, concessions, data collection, to live independently and be involved in society, to express, communicate, and obtain information, the right to move place and citizenship, as well as the right to be free from acts of discrimination, neglect, torture, and exploitation. Thus persons with disabilities have the right and obligation to engage in an engagement relationship.

Every legal relationship that is born both from an engagement and legislation always has two aspects, namely rights and obligations. Like every worker or laborer has the right to obtain protection. According to Article 86 Paragraph (1) of Law Number 13 of 2003 concerning Manpower, states that: "Every worker/laborer has the right to obtain protection for:

a. Occupational Health and Safety

b. morals and decency; and

c. treatment in accordance with human dignity and values and religious values. "

Labor rights are:

a. Requesting the leadership or management of the company to carry out all the required occupational safety and health requirements at the workplace concerned.

b. Expressing objections to working when safety and health requirements and personal protective equipment are required not to meet the requirements, except within limits that can still be accounted for (Husni 2005:133-136). 
Furthermore, Darwin Prints mentions several obligations from laborers, among others, as follows (Fahrojih 2016:40):

a. Must do an achievement/job for the employer.

b. Must comply with company regulations.

c. Must abide by the work agreement.

d. Must comply with labor agreements.

\section{Job Opportunities for Disability Workers at PT. Samwon Clothing Indonesia}

Most people with disabilities are in poor condition in other words the welfare of persons with disabilities is still underdeveloped and poor. This is because there are limitations to persons with disabilities such as the rights and access limitations of persons with disabilities. Whereas in Article 53 of Law Number 8 of 2016 concerning Persons with Disabilities has stated that: "Every company is obliged to accommodate persons with disabilities of at least $1 \%$ of the total workforce in the private sector and $2 \%$ in the government sector". From this paragraph, it can be concluded that each company whether it is a state-owned or private company is obliged to employ persons with disabilities with equal treatment and be fair so that persons with disabilities can meet their living needs.

Based on the recapitulation of data on people with disabilities, physical, and mental in 2017 and 2018 in the city of Semarang amounted to 1754 (Open Data Central Java: 2020). So it can be seen that the number of persons with disabilities in the city of Semarang is still relatively large. Even though the number of companies in both the formal and informal sectors in the city of Semarang should be able to absorb employment opportunities for the workforce, especially people with disabilities so as to reduce the unemployment rate and provide welfare for people with disabilities. Based on the results of interviews conducted by the author with the Department of Manpower and Transmigration in Central Java Province, the number of workers with disabilities working in the informal and formal sectors still tends to be small and most of the people with disabilities are still unemployed. Under the previous law governing persons with 
disabilities, companies are required to employ at least 1 employee with a disability for 100 employees. And after the issuance of Law Number 13 of 2003 concerning Manpower, companies are required to employ $1 \%$ of persons with disabilities from all employees (Interview Asih: 2020). If this is done well, it can reduce inequality and improve the living standards of persons with disabilities themselves. However, there are still many companies that do not heed these rules and still consider people with disabilities as people who do not have the ability and skills.

Fulfillment of the rights of persons with disabilities in the city of Semarang, in its policy the government of the City of Manpower and Transmigration of the City of Semarang provides job training/empowerment to persons with disabilities with the aim that persons with disabilities have the skills and abilities as provisions to get jobs in both formal and informal companies and can open businesses alone. Article 11 of Law Number 13 of 2003 concerning Manpower states that every workforce has the right to obtain and/or improve and / or develop work competencies in accordance with their talents, interests, and abilities through job training. This is reinforced by the existence of regulations for persons with disabilities attending training programs in accordance with Law Number 8 of 2016 concerning Persons with Disabilities contained in Article 46, which states that "The Government and Regional Governments must provide opportunities for Persons with Disabilities to take part in vocational training in Government, Regional Government and / or private vocational training institutions." Related to meeting the needs of people with disabilities in the city of Semarang, the Semarang Department of Manpower and Transmigration has provided work training programs for persons with disabilities, including training in fast sewing, sewing fashion, batik, make-up, make-up, cellphone technicians, computer operators, graphic design, catering, automotive, and sewing machine mechanics (Interview with Nunuk: 2020).

The training program provided for persons with disabilities is training in sewing, batik, and catering. In 2019 the government held 
an expo from the results of training of people with disabilities as a form of appreciation for people with disabilities for the abilities they have learned from the training program. As for the implementation of this training, there are weaknesses faced by the Semarang City Manpower and Transmigration Office, namely the lack of supporting infrastructure or infrastructure, this is still a barrier to training programs for persons with disabilities (Interview with Nunuk: 2020). In addition, most persons with disabilities who take part in the training are people with disabilities with less educational background. However, the existence of educators with adequate intellectual abilities provides opportunities for persons with disabilities to learn and gain work experience as provisions to find work according to their abilities. The same employment opportunities and legal protection for persons with disabilities in the city of Semarang are the same as stated in Law Number 8 of 2016 concerning Persons with Disabilities and Law Number 13 of 2003 concerning Manpower.

The Semarang City Manpower Office also holds a job fair that is open to anyone. This job fair procurement serves as a forum to provide opportunities for anyone seeking employment whether it is non-disabled or disabled. Job fair is participated by various state and private companies. One of them is PT. Samwon Busana Indonesia who often participates in this job fair event. This is done to provide equal employment opportunities for people with disabilities and reduce the unemployment rate (Interview with Nunuk: 2020).

PT. Samwon Busana Indonesia is a multinational company engaged in garment exports that provides employment opportunities for people with disabilities. The company is located in Candi Industrial Estate, Jl. Gatot Subroto Blok 11D, Ngaliyan, Semarang, 50182, Indonesia. PT. Samwon Busana Indonesia specializes in manufacturing men's clothing, women's clothing, and children's woven clothing. Total workers employed at PT. Samwon Busana Indonesia is 1317 workers, of which $93 \%$ are permanent workers. The company designs and manufactures well-known brands under license and has extensive inventory collaboration with several well-known 
brands. The majority of product markets in this company are US market orders (Company Profile: 2020).

PT. Samwon Busana Indonesia provides equal and fair treatment to all employees without discriminating against non-disabled employees or persons with disabilities. The employment opportunities provided by companies to employees with disabilities have no element of discrimination that can result in workers with disabilities feeling inferior (lacking confidence) or burdened in working at the company. PT. Samwon Clothing provides full support to employees who work in companies as well as persons with disabilities who are outside who are looking for work to meet their daily needs Interview Redi: 2020). The employees with disabilities at PT. Samwon Busana Indonesia, which already has provisions or abilities that have previously attended training organized by the government and employees with disabilities who received training from the company.

Table 1

Data on Persons with Disabilities and Company Profit of PT. Samwon Clothing Indonesia

\begin{tabular}{|l|l|l|l|l|l|}
\hline Year & $\begin{array}{c}\text { Total } \\
\text { Employ } \\
\text { ee }\end{array}$ & $\begin{array}{c}\text { Total } \\
\text { Disable } \\
\text { Employee }\end{array}$ & $\begin{array}{c}\text { Operating } \\
\text { Revenue }\end{array}$ & $\begin{array}{l}\text { Operating } \\
\text { Expenses }\end{array}$ & $\begin{array}{c}\text { Company } \\
\text { Profit }\end{array}$ \\
\hline 2017 & 1423 & 15 & $\begin{array}{l}138.593 .000 . \\
\text { ooo }\end{array}$ & $\begin{array}{l}112.635 .000 . \\
\text { ooo }\end{array}$ & $\begin{array}{l}25.958 .000 . \\
\text { ooo }\end{array}$ \\
\hline 2018 & 1335 & 14 & $\begin{array}{l}165 \cdot 357.000 . \\
\text { ooo }\end{array}$ & $\begin{array}{l}128.076 .000 \\
\text {.000 }\end{array}$ & $\begin{array}{l}37.281 .000 . \\
\text { ooo }\end{array}$ \\
\hline 2019 & 1322 & 14 & $\begin{array}{l}176.259 .700 . \\
318\end{array}$ & $\begin{array}{l}138.074 .864 . \\
068\end{array}$ & $\begin{array}{l}38.184 .836 .2 \\
50\end{array}$ \\
\hline
\end{tabular}

Source: HRD PT. Samwon Clothing Indonesia

Based on the data above since 2017-2019 there was an increase in corporate profits. If seen from the number of employees with disabilities from 2017-2019, it shows that PT. Samwon Busana Indonesia employs $1 \%$ of people with disabilities from the total number of employees. Although the total number of employees from 
the period of 2017-2019 decreased, the company still experienced an increase in the company's profit.

The data above shows that, employees with disabilities at PT. Samwon Busana Indonesia contributes to the company and does not interfere with company productivity. It can be seen that during the last 3 years from 2017-2019, non-disabled employees and people with disabilities helped to increase the productivity and profits of the company. Therefore, the employment of persons with disabilities does not impede the performance of the company, because it has been equipped with previous skills and training.

\section{Legal Protection for Disability Workers}

Legal protection is a form of providing protection for human rights that have been harmed by others and that protection is given to the community so that they can enjoy all the rights granted by law. Law is needed for those who are weak and not yet strong socially, economically, and politically to obtain social justice. So the granting of legal protection must be given to all people to respect human rights, including persons with disabilities. The form of protection for persons with disabilities is a conscious effort to protect, respect, and fulfill the rights of persons with disabilities.

In order to avoid gaps and discrimination against persons with disabilities, legal protection for persons with disabilities must be given from all aspects, one of which is to provide employment opportunities for persons with disabilities that are fair and equitable. In the world of work, persons with disabilities are entitled to receive the same treatment and equal opportunities in getting work without discrimination, this is in accordance with Article 5 of Law Number 13 of 2003 concerning Manpower. Therefore, to respect the rights of persons with disabilities, the Law regulates the legal protection of persons with disabilities, especially in matters of work to meet their needs. Legal protection for persons with disabilities in accordance with Article 67 Paragraph (1) of Law Number 13 of 2003 concerning Manpower states that: "Employers who employ workers with disabilities must provide protection in accordance with the type and 
degree of disability". Also stated in Article 9 of Law No. 8 of 2016 concerning Persons with Disabilities that persons with disabilities obtain the right to justice and legal protection to be treated equally before the law in providing accessibility and protection from all pressures, violence, abuse, discrimination, and/or expropriation or expropriation of property rights.

The provision of legal protection for persons with disabilities is given based on the principles of humanity and justice. As the principles of justice put forward by John Rawl, who asserted that the enforcement of justice must have a dimension that is concerned with two principles of justice, namely First, giving equal rights and opportunities to the broadest basic freedoms as much freedom for everyone. So in relation to this, in protecting the rights of persons with disabilities to be free to choose and get equal and fair employment opportunities and there is no element of discrimination from company actions, it is necessary to have a supervisory body that oversees the performance of employers. In the city of Semarang itself, labor is supervised by the supervisory staff of the Office of Manpower and Transmigration in Central Java Province. In providing supervision. The duty and authority of the labor inspector is to provide guidance and supervise. Such as fostering labor norms, Central Java Province Manpower and Transmigration Office supervisory staff to protect the rights of persons with disabilities, supervisory employees will provide companies with an understanding that persons with disabilities are also entitled to receive jobs, advise employers to provide guidance to persons with disabilities, that companies must employ at least $1 \%$ of all workers in the company. If the company does not provide employment opportunities to persons with disabilities, supervisory staff will provide a memorandum of inspection as a form of reprimand to the company (Interview with Asih: 2020).

The duties and authority of other supervisory employees are to supervise every company that carries out compulsory reporting. Based on the results of the interview, so far PT. Samwon Busana Indonesia has carried out compulsory reporting in its entirety each 
year to the Manpower Office and reported the overall number of employees both non-disabled and persons with disabilities who work at PT. Samwon Clothing Indonesia. The form of legal protection provided by the Semarang City Manpower and Transmigration Office and the Central Java Province Manpower and Transmigration Office is to provide direction and outreach to employers and provide instruction to persons with disabilities in order to obtain their rights (Interview with Asih: 2020). So, both the government and the company PT. Samwon Busana Indonesia has given equal rights and opportunities on the basis of freedom to persons with disabilities as facilitators to meet the needs and rights of persons with disabilities.

The second principle of justice according to John Rawls is being able to rearrange social-economic inequality so as to provide mutual benefits. Justice for persons with disabilities to obtain welfare meets their needs, mandatory for state and private companies to employ workers with disabilities. By employing workers with disabilities will have a positive impact, namely, there is a beneficial reciprocal relationship between the two. Companies will benefit from having workers with disabilities to increase company productivity, while workers with disabilities will benefit from being able to meet their economic needs. However, many companies still look down on workers with disabilities because they are considered to have no ability and have low thinking power. However, if workers with disabilities are trained and given knowledge, the reverse will be beneficial for companies that employ them because they can increase productivity. The theory of justice put forward by John Rawls prioritizes the equality of human dignity in order to obtain his rights equally and equally. So with this, PT. Samwon Busana Indonesia, which is a private company, has been able to provide equal employment opportunities and provide justice for people with disabilities by employing them in the company.

The following forms of legal protection provided by PT. Samwon Busana Indonesia on the rights of persons with disabilities, including:

a. Protection of Persons with Disabilities 
Article 67 Paragraph (1) of Law Number 13 of 2003 regarding Manpower states that: "Employers who employ workers with disabilities are required to provide protection in accordance with the type and degree of disability". In relation to this matter, PT. Samwon Busana Indonesia provides protection to its employees both disabled and non-disabled workers according to their degree. Legal protection provided by PT. Samwon Busana Indonesia to all of its employees has been stated in the Company Regulations. Within the company, there is a bipartite committee that functions as a communication agency between management and employees (Interview with Redi: 2020).

Regarding employee aspirations, all employees are also given the freedom to express complaints and are free to express their opinions which can be conveyed directly to superiors or through intermediaries that can be conveyed to company HRD, suggestion boxes, or through bipartite institutions (Interview with Redi: 2020). With the opportunity to express this complaint, it is an effective way for persons with disabilities as a form of counseling to help openness and discuss issues faced by employees with disabilities in the work environment. In addition, the company also guarantees the confidentiality of opinions and complaints conveyed by employees.

b. Article 11 of Law Number 8 of 2016 mentions the rights of persons with disabilities regarding employment opportunities, including the following:

1. Obtain work carried out by the Government, Regional Government, or the private sector without discrimination.

Regarding this article, PT. Samwon Busana Indonesia in assisting persons with disabilities to obtain employment without discrimination has opened equal opportunities to persons with disabilities by opening job vacancies regardless of the workforce of persons with disabilities or non-disabled. However, the fulfillment of employment opportunities for persons with disabilities mostly in PT. Samwon Busana Indonesia is currently only disabled by the physically challenged and deaf (Interview with Redi: 2020). For persons 
with disabilities who are blind or speech impaired do not yet exist at PT. Samwon Busana Indonesia, so workers with disabilities who work at PT. Samwon Clothing Indonesia is not comprehensive.

2. Obtain the same wages as workers who are not disabled with the same type of work and responsibilities

Based on Article 88 Paragraph (1) of Law Number 13 of 2003 concerning Manpower states that every worker/laborer has the right to earn income that meets a decent living for humanity. Where the amount of income or income of workers/laborers from the work results can meet the needs of workers/laborers and their families in a reasonable manner which includes food and beverages, clothing, housing, education, health, recreation, and old-age insurance.

Protection of the rights of persons with disabilities related to regulations on wages in PT. Samwon Busana Indonesia is every employee who works in a company receiving a basic salary in cash in accordance with the MSE and wage provisions that apply to account payments and employee benefits. The company pays salaries to employees every 5 th. In addition, the company also provides benefits in the form of food allowances, overtime pay, health insurance, old-age insurance, work accident insurance, life insurance, and pension insurance. Regarding the salary deduction of PT. Samwon Busana Indonesia, the company will cut salaries to employees for loss to follow-up, salary deductions for leaving work without permission, deductions from BPJS Employment contributions and BPJS Health, union discounts (Interview with Redi: 2020).

Based on information from employees at PT. Samwon Busana Indonesia, both persons with disabilities and nondisabled, receive salaries by the company on time and there is never a delay in receiving wages. All salaries given are in accordance with regulations and agreements made by employees and companies (Employee Interview: 2020).

3. Obtain accessibility and adequate accommodation at work 
Appropriate accommodation is the appropriate modification and adjustment needed to ensure the enjoyment or implementation of all human rights and fundamental freedoms for persons with disabilities based on equality. If the employer does not provide adequate accommodation and facilities that are easily accessible by workers with disabilities, based on Article 50 of Law Number 8 of 2016, employers will be subjected to administrative sanctions in the form of written warnings, termination of operational activities, suspension of business licenses, and revocation of business licenses.

Provision of accommodation such as employee buses, at PT. Samwon Clothing Indonesia is currently not provided. However, employees at PT. Samwon Clothing Indonesia received a transportation allowance from the company. The interview that the writer did with the employees of PT. Samwon Busana Indonesia said that the company used to provide accommodation in the form of employee buses but in recent years the company did not provide employee buses. Nevertheless employees at PT. Samwon Clothing Indonesia, especially for people with disabilities, does not find it difficult to go to work. Because the company provides transportation allowances and the treatment given by the company is very good (Interview with Redi: 2020).

Legal protection is given by PT. Samwon Busana Indonesia in improving welfare for its employees, the company has complied with existing laws and regulations and provides welfare facilities. As stated in Article 99 of Law Number 13 of 2003 concerning Manpower, states that "Every worker/laborer and his family are entitled to obtain labor social security". In this case, PT. Samwon Busana Indonesia provides social welfare to its employees in the form of Employment Social Security, Health Social Security, Social Security for newborns, care and treatment, provision of medicines and antibiotics from company polyclinics, parking facilities, places of worship, toilet facilities (Interview with Redi: 2020). 
Accessibility according to Article 1 Paragraph (8) of Law Number 8 of 2016 concerning Persons with Disabilities is the convenience provided for persons with disabilities to realize equality of opportunity. Fulfillment of accessibility such as prayer rooms, toilets, either toilet seat or squat, polyclinic, fire extinguisher and first aid (fire extinguisher and first aid), personal protective equipment, and hydrants are available at PT. Samwon Clothing Indonesia. However, accessibility such as stairs specifically for persons with disabilities in the company does not yet exist. Because of employees with disabilities at PT. Samwon Busana Indonesia at this time the degree of disability can be said to be still mildly handicapped so that the provision of accessibility for persons with disabilities is still the same as non-disabled employees (Interview with Redi: 2020). Thus the company has not fully met the accessibility for employees with disabilities whereas based on the laws and regulations, all accessibility for employees with disabilities must exist.

Based on the results of interviews conducted by the author with disabled employees at PT. Samwon Busana Indonesia, the lack of accessibility for employees with disabilities in the company does not hamper the performance of persons with disabilities themselves. Because the company pays attention and compensates employees with disabilities if there are complaints. because work placement for people with disabilities is adjusted to the needs and degree of disability of persons with disabilities themselves (Employee Interview: 2020).

4. Fair, proportionate and dignified work placement

PT. Samwon Busana Indonesia in the recruitment of workers, the company will still accept applicants both with disabilities and non-disabled. For applicants with disabilities, carry out the same procedure with non-disabled applicants, namely showing a job application letter and other requirements. After that, it will go through several stages of selection such as administrative tests, written tests, 
psychological tests, interviews, and medical tests. If the stages are successfully passed and declared to have passed then the company will be accepted for training for three months. The training period (training) aims to make employees more familiar with the company, to know the correct work procedures and the description of the tasks that must be performed by employees. The form of training conducted by PT. Samwon Clothing Indonesia is like training in QC Training, $\mathrm{CoC}$ and C-TPAT training, OSH and First Aid training, and training in fire fighting (Interview Redi: 2020). Training conducted by employees with disabilities at PT. Samwon Busana Indonesia is the same as non-disabled employees, but all of it is adjusted to the type and degree of disability of persons with disabilities. Regarding the placement of employees with disabilities by companies for the type of work adapted and allow people with disabilities to do it.

c. Working Time

Based on Article 77 of Law Number 13 of 2003 concerning Manpower, states that employers must carry out the provisions of working time with the provisions of 7 hours 1 day and 40 hours 1 (one) week for 6 working days in 1 week, 8 hours 1 day and 40 hours 1 week for 5 working days in 1 week. If it exceeds these conditions workers must be given overtime pay. Working time at PT. Samwon Clothing Indonesia is 6 working days, namely Monday, Tuesday, Wednesday, Thursday, Friday, and Saturday. Working time for Monday to Friday starts at 07.30-15.30 WIB so it is as much as 8 hours per day with rest time to eat and perform worship which is one hour per day. While for Saturday, work time starts at 07.30-13.00 WIB (Interview with Redi: 2020).

Determination of working time at PT. Samwon Busana Indonesia is based on an agreement from the company with employees, where if there are additional overtime hours for employees, the company will continue to pay overtime in accordance with applicable provisions in applicable law. According to employees at PT. Samwon Busana Indonesia giving 
work hours is not a problem as long as the company provides appropriate and timely wages. So until now, no employee has filed a complaint about working hours at PT. Samwon Clothing Indonesia.

d. Occupational Safety and Health

Based on the statement, every employer must provide and implement an Occupational Safety and Health $\left(K_{3}\right)$ management system to minimize workplace accidents. In relation to this matter, PT. Samwon Busana Indonesia has provided this $K_{3}$ system whose purpose is to minimize work risks due to work accidents or illness. However, this management system applies to all employees at PT. Samwon Busana Indonesia and there are no rules that specifically address persons with disabilities.

Some of PT Samwon Busana Indonesia's industrial activities carry dangerous risks that have the potential to cause adverse incidents and can disrupt business. Therefore the management of PT Samwon Busana Indonesia agreed with a major and ongoing commitment in terms of protecting employees as the company's most important assets, company property, and environmental protection from a loss that is not expected by all parties. The purpose of this commitment is not just to meet Occupational Health and Safety $\left(K_{3}\right)$ standards, but also to act positively in terms of preventing injury, illness, property damage, fire, blasting, and loss arising from PT Samwon's work operations Indonesian Clothing (Interview from Diskta: 2020).

This policy is reviewed annually and will be re-issued if necessary changes are made in order to improve the Company's HSE performance. In addition, PT. Samwon Busana Indonesia also gives time workers a dispensation for women workers who feel pain during menstruation, women workers who will give birth, and women workers who breastfeed. Based on the results of an interview with one of the polyclinic doctors at PT. Samwon Busana Indonesia, the company provides time off for workers who will give birth and rest after giving birth. Each rest is 1.5 months. This is given in accordance with applicable law. Whereas sick workers will be given a dispensation for a break if the worker 
submits a sick certificate given from the polyclinic stating that the worker is sick (Interview from Diskta: 2020).

Based on the results of interviews with persons with disabilities found in PT. Samwon Busana Indonesia, who works in the production, operator, and cleaning service sectors, does not experience any obstacles or obstacles in carrying out her work. Like Ms. Ismu, she is a worker with a disability where her toes are absent. He was given a dispensation by a company that at work was supposed to wear shoes but got a dispensation for wearing sandals at work after obtaining permission from the clinic and personnel (Interview with Ismu: 2020).

e. Termination of Employment

Industrial relations based on Article 1 Paragraph (16) of Law Number 13 of 2003 concerning Manpower is a system of relations formed between actors in the process of producing goods and/or services consisting of elements of employers, workers/laborers, and the government based on Pancasila values and the 1945 Constitution. Industrial relations related to the termination of employment (FLE) at PT. Samwon Clothing Indonesia there is no such thing as layoffs. Employees who resign both non-disabled employees or persons with disabilities are all in accordance with company procedures, namely submitting written submissions at least 30 days before resigning and continuing to carry out their obligations and will be given the right of remaining unpaid salaries, the remaining annual leave that has not been taken, and the cord of love according to company regulations and work experience letters (Interview with Redi: 2020).

In strengthening industrial relations with its employees, the efforts carried out by the company are as follows:

1. Hold regular formal and informal meetings at least once a month to discuss and find a way out or resolve employment problems that may arise.

2. Employers and employees form a Bipartite cooperation institution whose members are representatives from all departments and sections as well as representatives from employers. 
Both employees with disabilities and non-disabled who work at PT. Samwon Busana Indonesia has not experienced any layoffs. In particular, employees with disabilities receive equal and fair treatment. Legal protection is given to persons with disabilities against the fulfillment of the rights of persons with disabilities related to work, especially employees with disabilities at PT. Samwon Clothing Indonesia must be adapted to the ability and degree of disability of persons with disabilities themselves. PT. Samwon Busana Indonesia provides equal opportunities and legal protection to all its employees in accordance with applicable laws and regulations.

Providing opportunities and protection for persons with disabilities at PT. Samwon Busana Indonesia is equated with nondisabled employees in terms of facilities, access, guarantees, wages, working time, and other aspects. Although in company regulations PT. Samwon Busana Indonesia does not specifically mention persons with disabilities, but all regulations that apply in the company still apply to persons with disabilities. So at PT. Samwon Busana Indonesia does not discriminate against employees with disabilities.

\section{Conclusion}

Job opportunities for persons with disabilities at PT. Samwon Clothing Indonesia has been fulfilled and in accordance with Law Number 13 of 2003 concerning Manpower. PT. Samwon Busana Indonesia is one of the private companies in the city of Semarang, this company is engaged in the garment industry or the textile industry. PT. Samwon Busana Indonesia has fulfilled $1 \%$ employing people with disabilities in the company, namely 14 employees out of all 1317 employees. All employees, both non-disabled and disabled, have the opportunity, fair treatment, and fulfillment of the rights of persons with disabilities fulfilled without discrimination. However, employees with disabilities who work at PT. Samwon Clothing Indonesia is mostly deaf and deaf, while for people with disabilities such as the blind, speech impaired, the company has not hired him. Job opportunities provided by PT. Samwon Clothing Indonesia for people 
with disabilities is adjusted to the degree of disability from persons with disabilities themselves. The company provides full support to employees with disabilities and helps increase the productivity of the company itself.

Legal protection for persons with disabilities is based on the principles of justice according to John Rawls, namely ensuring that all people get equal justice both the rights and opportunities of every human being must be fulfilled. For this reason, both the government and the PT. Samwon Busana Indonesia has provided forms of job training for persons with disabilities to improve their abilities and skills, besides providing equal rights and opportunities on the basis of freedom for persons with disabilities to choose and find work, where the government and PT. Samwon Busana Indonesia as a facilitator to meet the needs and rights of people with disabilities. Form of legal protection for persons with disabilities in fulfilling their rights, PT. Samwon Busana Indonesia has already carried out in accordance with the applicable laws and regulations. PT. Samwon Busana Indonesia has accepted and employed persons with disabilities taking into account the degree of disability from persons with disabilities. In addition, as stated in Law Number 13 of 2003 concerning Manpower and Law Number 8 of 2016 concerning Persons with Disabilities that forms of legal protection such as employment opportunities, wage protection, accommodation, accessibility, working time, the fulfillment of $\mathrm{OSH}$, as well as industrial relations have been fulfilled and there are no work violations committed by companies. However, accessibility in PT. Samwon Busana Indonesia is still lacking, as the accessibility of special stairs for persons with disabilities has not been provided by the company. In addition accommodations such as transportation for employees are also not provided. [w]

\section{Reference}

Amirudin and Zaenal Asikin. 2004. Pengantar Metode Penelitian Hukum. Jakarta: Raja Grafindo Persada. 
Badan Pusat Statistik. 2019. "Tenaga Kerja." BPS. Retrieved (http://www.bps.go.id/subject/6/tenaga-kerja.html).

Busana, Sawon. 2015. "PT Sawon Busana." Retrieved (http://samwonbusana.com/page/80032/green-factory.html).

Fahrojih, Ikhwan. 2016. Hukum Perburuan Konsepsi, Sejarah, Dan Jaminan Konstitusional. Malang: Setara Press.

Hadjon, Phillipus M. 1987. Perlindungan Hukum Bagi Rakyat Indonesia. Surabaya: Bina Ilmu.

Husni, Lalu. 2005. Pengantar Hukum Ketenagakerjaan. Jakarta: Raja Grafindo Persada.

Interview with Redi Adji K, 21 Januari 2020

Interview with Diskta Winza Ronica, 27 Januari 2020

Interview with Ismu Khoiriah, 27 Januari 2020.

Interview with Suwarti, 27 Januari 2020

Interview with Asih, 24 Februari 2020.

Interview with Nunuk, 11 Februari 2020.

Mertokusumo, Sudikno. 2007. Mengenal Hukum: Suatu Pengantar. Yogyakarta: Liberty.

Pemerintah RI. 1945. “Undang-Undang Dasar Tahun 1945”

Pemerintah RI. 2003. "Undang-Undang Nomor 13 Tahun 2003 tentang Ketenagakerjaan"

Pemerintah RI. 2016. "Undang-Undang Nomor 8 Tahun 2106 tentang Penyandang Disabilitas"

Pemerintah RI. 2019. "Peraturan Pemerintah Nomor 52 Tahun 2019 tentang Penyelenggaraan Kesejahteraan Sosial Bagi Penyandang Disabilitas"

Pemerintah RI. 2019. "Peraturan Pemerintah Nomor 70 Tahun 2019 tentang Perencanaan, Penyelenggaraan, dan Evaluasi Terhadap Penghormatan, Perlindungan, dan Pemenuhan Hak Penyandang 


\section{Disabilitas"}

Raharjo, Satjipto. 2000. Ilmu Hukum. Bandung: Citra Aditya Bakti.

Rahayu, Sugi, Utami Dewi and Marita Ahdiyana. 2013. "Pelayanan Publik Bidang Transportasi Bagi Difabel Di Daerah Istimewa Yogyakarta." Jurnal Ilmu-Ilmu Sosial 10(2):108-19.

Reefani, Nur Kholis. 2013. Panduan Anak Berkebutuhan Khusus. Yogyakarta: Imperium.

Situmorang, Boyke T. .. 2005. Elastisitas Kesempatan Kerja Terhadap Pertumbuhan Ekonomi, Upah Minimum Dan Suku Bunga Di Indonesia Tahun 1990-2003.

Tambunan. 2002. Tenaga Kerja. Yogyakarta: Bpfe. 